If the results are accepted as comparable it is clear that the new method is at least twenty times as efficient as the standard method in that twenty times less antigen was used to produce similar results. Furthermore, it is, as Goudie et al. ${ }^{1}$ havo shown, suited to preparing antibody to the small quantities of antigen contained in an immune procipitate after the fashion of Smith et al. ${ }^{3}$. We are now following this avenue as a means of pursuing the devclopment and function of non-particulate antigens formed during the growth of herpes virus.

We believe that this technique will prove to have general usefulness in virology.

D. H. W. was a member of the Medical Research Council Virus Research Group during part of this work.

P. WIINY

D. H. WATSON

Department of Virology,

Medical School,

Birmingham 15.

Received May 6, 1968.

2 Goudie, R. B., Horne, C. H. W., and Wilkinson, P. C., Lancet, ji, 1224 (1966). 'Watzon, D. H., Shedden, W. I. H., Elliot, A., Tetsuka, T., Willy, P., Bourgaux-Ramoisy, D., and fold, E., Immunology, 11, 399 (1968).

${ }^{3}$ Smith, H., Gallop, R. C., and Tozer, B. T., Immunology, 7, 111 (1986).

\section{Control of Growth of Axenic Cultures of Mammalian Cells by Serum Lipids}

Although serum proteins are almost universally used to stimulate the growth of mammalian cells in axenic culture, the nature of the active entity is unknown. Previous work from this laboratory ${ }^{1}$ has shown that lipids extracted from serum with ether are toxic to cultured colls. It therefure seemed reasonable that the removal of toxic materials would produce serum of greater growth stimulatory activity. This was found not to be so; the resulting serum was either toxic or inert to cultured cells. The reason for this may have been that ether extraction was too vigorous a treatment for the retention of growth stimulatory activity by serum proteins. A milder method would be the uso of chareoal which was shown by Chen ${ }^{2}$ to remove fatty acids from serum albumin.

This procedure was applied to calf serum which was then tested for residual lipid content. Charcoal-treated calf serum ( $2 \mathrm{ml}$.) and $2 \mathrm{ml}$. of native calf serum were extracted three times with $2 \mathrm{ml}$. of ether. Evaporation of the ether and drying over $\mathrm{P}_{2} \mathrm{O}_{5}$ in a vacuum gave $0 \cdot 10$ and $0.50 \mathrm{mg}$ of residues from the delipidated and native calf sera, respectively. Removal of lipid did not alter appreciably tho olectrophorotic pattern obtained on acetylated cellulose ${ }^{3}$ at $p H \mathbf{H} \cdot 6$. Table 1 shows the distribution of the proteins.

Table 1. hLECTROPHORETIC SEPARATION OF THE PROTEINS IN NATTVE AND CHARCOAL-DELIPIDATED CALF SERUM

\begin{tabular}{|c|c|c|c|c|c|}
\hline & & obuliı & & Albumin & Total \\
\hline & $\gamma$ & & $\alpha$ & & ieln \\
\hline $\begin{array}{l}\text { Calf serum } \\
\text { Defatted serum }\end{array}$ & $\begin{array}{l}0.632 \\
0.604\end{array}$ & $\begin{array}{l}0 \cdot 653 \\
0.483\end{array}$ & $\begin{array}{l}0.784 \\
0.814\end{array}$ & $\begin{array}{l}1 \cdot 13 \\
0.90\end{array}$ & $\begin{array}{l}3 \cdot 20 \\
2 \cdot 50\end{array}$ \\
\hline
\end{tabular}

Units are g/100 ml.

The two sera were compared for their ability to stimulate the growth of a cell lino derivod from a small bowel carcinoma of the Syrian hamster ${ }^{4}$ in suspension culture in Roswell Park Memorial Institute Modium No. 1379 (ref. 5). The assays were performed as described earlier ${ }^{8}$ in $30 \mathrm{ml}$. "spinner flasks" (Bellco) and cells were counted in a haemocytometer in the presence of trypan blue. The protein contont of both serum samples was determined by the biuret method ${ }^{7}$ with human serum albumin as the standard. Eight concentrations of calf serum protein between 0.001 and $1 \mathrm{mg}$ of protein $/ \mathrm{ml}$. were assayed. Typical growth curves are shown in Fig. 1. 'These data

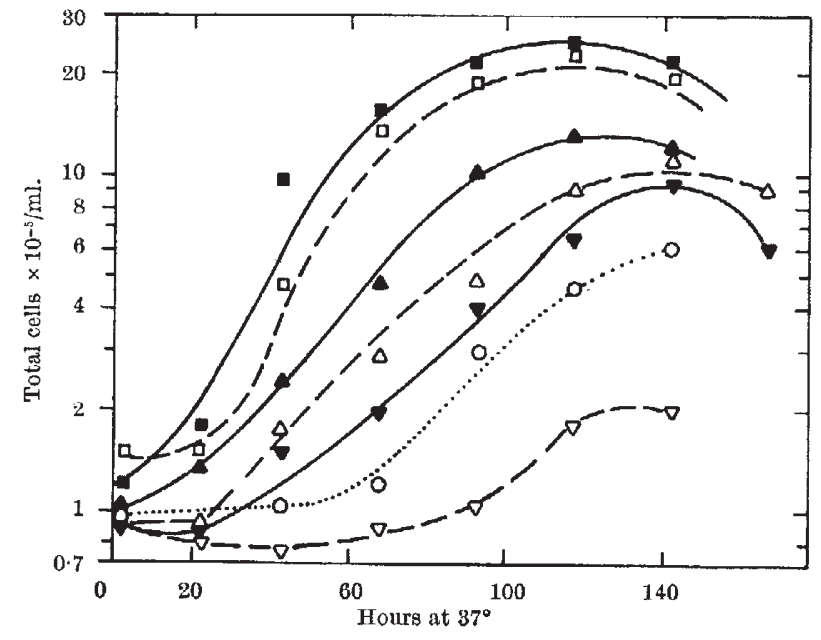

Fig. 1. Cell growth in the presence of $1(\square \square), 0.01(\Delta \Delta), 0.001$ $(\nabla /)$ and zero $(0) \mathrm{mg}$ of calf scrum protein/mi. The solid curve and and open syubols the delipidated calf serum and the broken curve is indicated by the dotted line and cireles.

indicate that: (1) although there was no lag poriod in the presence of $0.01 \mathrm{or} 1 \mathrm{mg}$ of calf serum protein $/ \mathrm{ml}$., these concentrations of delipidated serum resulted in a $24 \mathrm{~h}$ lag. (2) In no instance was the delipidated serum better able to stimulate the growth than a comparable level of native calf serum. (3) Relative to the control assay in serum-free medium, a concentration of $1 \mu \mathrm{g}$ of delipidated calf sorum protein $/ \mathrm{ml}$. was toxic while the same concentration of native calf serum stimulated growth.

The growth stimulatory activity of calf serum does not appear to be equal to the sum of the activities of its constituents. Although high concentrations of delipidated calf serum aro clearly growth stimulatory, low concentrations are toxic relative to the protein-free medium. This implies that a concentration-dependent dissociation (which may be irreversible) between growth stimulatory and toxic entities regulates the activity of calf serum. This may be the reason for the consistent failure by numerous workers $^{8-11}$ to isolate the active principle of serum. Furthermore, an isolated entity with either toxic or growth stimulatory activity may be an artefact produced during the purification procedure and not represent the active entity of native serum at all.

This work was supported in part by grants from the American Cancer Society and the US Public Health Service. We thank Miss V. P. Juliano for the elcctrophoretic analyses.
G. L. Tritsor
J. A. BELI
G. Grahl-NimLsen

Roswell Park Memorial Institute,

New York State Department of Health, Buffalo, Now York.

Recelved April 29, 1968.

${ }^{1}$ De Luca, C., Carruthers, C., and Tritsch, G. L., Exp. Cell Res., 43, 451 $(1966)$.

${ }^{2}$ Chen, R. F., J. Biol. Chem., 242, 173 (1967).

${ }^{3}$ Grunbaum, B. W., Zec, J., and Durrum, E. I., Microchem. J., 7, 41 (1963). - Moore, G. E., Mount, D., Tara, G., and Schwartz, N., J. Nat. Cancer Inst.,
31, 1217 (1963).

'Moore, G. E., and Ulrich, K., J. Surg. Res., 5, 270 (1965).

Tritsch, G. L., Bell, J. A., and Grahl-Nielsen, G., Exp. Cell Res, 48, 244 (1967).

'Gornall, A. G., Bardawill, C. J., and David, M. M., J. Biol. Chem., 177, 751

, Fed. Proc., 21, 157 (1962)

${ }^{9}$ Fischer, H. W., Puck, T. T., and Sato, G., J. Exp. Med., 109, 649 (1950),

10 Lieberman, I., and Ove, P., J. Biol. Chem., 234, 2754 (1959).

11 Michl, J., and Rezácová, D., Acta Virol., 10, 254 (1966). 